\title{
ALTERATION OF PEROVSKITE TO ANATASE IN SILICA- UNDERSATURATED ROCKS OF THE CATALÃO-I CARBONATITE COMPLEX, BRAZIL: A RAMAN STUDY
}

\author{
VITOR PAULO PEREIRA ${ }^{1}$, ROMULO VIEIRACONCEIÇÃ ${ }^{1}$, \\ MILTON LUIZ LAQUINTINIE FORMOSO ${ }^{1}$ \& AMANDACRISTINA PIRES
}

\begin{abstract}
Resumo ALTERATION OF PEROVSKITE TO ANATASE IN SILICA-UNDERSATURATED ROCKS OF THE CATALÃO-I CARBONATITE COMPLEX, BRAZIL: A RAMANSTUDY A transformação de perovskita para anatásio decorrente da intrusão de um carbonatito foi investigada usando microssonda eletrônica, imagens de elétrons retroespalhados, mapas de distribuição de elementos por dispersão de energia e perfis de composições químicas no microscópio eletrônico de varredura e espectroscopia Raman. Os cálculos de balanço de massa entre a perovskita e o anatásio permitiram verificar que com o processo de alteração houve a lixiviação de $\mathrm{Ca}, \mathrm{Nd}$, Ce e $\mathrm{Na}$ e a concentração relativa de $\mathrm{Ti}, \mathrm{Si}, \mathrm{Mg}, \mathrm{Zr}, \mathrm{Nb}$ e Fe. A presença de uma "camada de Ti" amorfa $(>1 \mathrm{~mm}) \mathrm{na}$ superfície dos grãos foi investigada. Os espectros Raman confirmam a existência de uma fase intermediária composta por perovskita alterada anterior a cristalização do anatásio. Não foi possível reconhecer um limite entre a perovskita alterada e a inalterada devido a heterogeneidade no processo. A estrutura da perovskita muda antes da lixiviação do cálcio. O processo culmina com a cristalização de anatásio, quando o cálcio é lixiviado e a estrutura colapsa. O processo de alteração pela ação do fluido carbonatítico é diferente daquele descrito na literatura, onde o cálcio é lixiviado em dois estágios para formar o anatásio.
\end{abstract}

Palavras-chave: perovskita, anatásio, Catalão-I, espectroscopia Raman, Brasil.

\begin{abstract}
The transformation of perovskite into anatase due to a carbonatitic emplacement was investigated using electron microprobe, back-scattered electron images, element-distribution maps, chemical composition profiles and Raman spectroscopy. The mass balance calculations between perovskite and anatase indicate that $\mathrm{Ca}, \mathrm{Nd}, \mathrm{Ce}$ and $\mathrm{Na}$ are leached and $\mathrm{Ti}, \mathrm{Si}, \mathrm{Mg}, \mathrm{Zr}, \mathrm{Nb}$ and Fe are relatively concentrated. The presence of an amorphous "Ti-layer" $(>1 \mathrm{~mm})$ on the surface of the grains was investigated. Raman spectra confirm the existence of an intermediate phase composed by altered perovskite previously to the anatase crystallization. It is not possible to recognize a limit between the unaltered and altered perovskite, due to the heterogeneity of the process. The perovskite structure changes before the leaching of calcium. This process culminated with the crystallization of anatase when the calcium is leached and the structure collapses. The alteration process by the carbonatic fluid action is different from that induced by weathering which promote the leaching of calcium and the anatase genesis in two stages.
\end{abstract}

Keywords: perovskite, anatase, Catalão-I, Raman spectroscopy, Brazil.

INTRODUCTION Perovskite, ideally $\mathrm{CaTiO}_{3}$, is a ubiquitous accessory mineral in $\mathrm{SiO}_{2}$-undersaturated rocks such as kimberlites, melilitites, foidites, olivinites, clinopyroxenites and carbonatites. It is also the principal component of a synthetic assemblage of titanate phases known as SYNROC, a potential nuclear waste form (Ringwood et al. 1979). Depending on $\mathrm{P}\left(\mathrm{CO}_{2}\right)$, perovskite is a stable phase in many magmatic assemblages. However, thermodynamic calculations have clearly shown that perovskite is unstable at low temperatures. Alteration of perovskite by subsolidus re-equilibration, metasomatic and secondary alteration, produces other Ti-bearing minerals such as titanite and $\mathrm{TiO}_{2}$ polymorphs [rutile, anatase and brookite, $\left.\mathrm{TiO}_{2}(\mathrm{~B})\right]$ ilmenite, and (Nb,Ti,Fe,Ta) ${ }_{2} \mathrm{O}_{5}$ (Mitchell \& Chakhmouradian 1998, Chakhmouradian \& Mitchell 2000). The alteration processes which transforms perovskite to metastable $\mathrm{TiO}_{2}$ polymorphs anatase, brookite and $\mathrm{TiO}_{2}(\mathrm{~B})$ instead of rutile is poorly understood (Banfield, et al., $1991 \mathrm{a}$ and $\mathrm{b}$ ). The difference between the stabilities of these minerals is small at low temperatures (Post \& Burnham 1986). However, anatase is the most stable polymorph in alkaline rocks and associated carbonatites from Alto Paranaiba alkaline province (Brazil). The presence of rare-earth oxides seems to facilitate crystallization of anatase (Hishita et al. 1983). The mechanism that controls such alteration has been the subject of many studies.

The alteration of perovskite to anatase from the Catalão-I Alkaline Complex (Brazil) was studied using Raman spectroscopy, element-distribution maps, chemical profiles and electron microprobe analysis. The primary objective of our study was discuss the process of alteration of perovskite to anatase. According to Banfield \& Veblen (1992), Jostsons et al. (1990) summarized an experimental work on perovskite dissolution including data of Pham et al. (unpublished data) which suggest that under epithermal conditions an amorphous film forms on the perovskite surface. Another objective is to investigate the presence or not of an amorphous Ti-rich layer larger than $1 \mu \mathrm{m}$.

Banfield \& Veblen (1992), in transmission-electron microscopy studies, did not present any evidence for an amorphous Ti phase along the interface between anatase and perovskite. In this case, the alteration should occur by incongruent dissolution of

1 - Instituto de Geociências, Universidade Federal do Rio Grande do Sul, Av. Bento Gonçalves, 9.500 - Porto Alegre - RS, CEP.: 91.501-970, vitor.pereira@ufrgs.br 
perovskite crystals, in spite of the extremely low Ti solubility under weathering conditions, and anatase would be the product of crystallization from this layer.

ANALYTICALTECHNIQUES Compositional maps of elements and chemical profiles were acquired using X-ray energy-dispersion spectrometry (EDS) using a JEOL, JSM-5800 scanning electron microscope at the Center of Electron Microscopy of Universidade Federal do Rio Grande do Sul, Brazil. The element-distribution map images were acquired for 30 minutes and the chemical profiles for 10 minutes. The mineral compositions were determined by electron microprobe analysis (EMPA) using a Cameca SX50 wavelength dispersive electron probe microanalyser operating at $15 \mathrm{kV}$ and 10 $\mathrm{nA}$ specimen current. The Raman spectra were recorded at room temperature using a HeNe laser source with a wavelength of 632.8 $\mathrm{nm}$ and nominal power of $30 \mathrm{~mW}$. The power of the laser in the surface of the sample was $10 \mathrm{~mW}$ and the diameter of the spot 1 $\mathrm{mm}$. The Raman signals were collected for one monochromator and the radiation was detected by a charge coupled device camera cooled by liquid nitrogen. The resolution of spectra was $4-5 \mathrm{~cm}^{-1}$ and the wavenumber accuracy was next to $1 \mathrm{~cm}^{-1}$. The spectra were recorded between 350 and $2260 \mathrm{~cm}^{-1}$.

PARAGENETICRELATIONSOFPEROVSKITE Theperovskite and anatase studied originate from the Catalão-I Alkaline Complex (Goiás-Brazil) situated at $18^{\circ} 08^{\prime} \mathrm{S}, 47^{\circ} 48^{\prime} \mathrm{W}$. The geology of CatalãoI has been described in detail elsewhere (Carvalho 1974a,b, Baecker 1983, Pereira 1995). Host rocks are composed of magmatic "phoscorites" and pyroxenites, intruded by carbonatites and hydrothermal apatitites. All rocks are cut by barite and quartz veins. The superposition of different magmatic and hydrothermal events makes the Catalão-I rocks very heterogeneous. One typical sample from a depth of $470 \mathrm{~m}$ (drill 49E35N) was selected for Raman analyses. The petrographic study of this sample made possible identify altered olivine (serpentine?), tetraferriphlogopite, perovskite, anatase, dolomite, apatite, ilmenite, pyrite and pyrochlore. Perovskite grains are partially or completely transformed to anatase and olivine to serpentine (?) due to the reaction with a carbothermal fluid. The reaction with this fluid promote also the crystallization of needles ( $<1 \mathrm{~mm}$ width) of a not identified Ba-LREE carbonate (Fig. 1), that has different microscopic characteristics from those Ba-LREE carbonates described in literature. The source of $\mathrm{Ba}$ is not identified, but the REE could be from different minerals, specially from perovskite. According to Kukharenko et al. (1965) and Mitchell $(1986,1996)$, perovskite is the principal host for LREE in undersaturated ultramafic and alkaline rocks. The carbothermal fluid leach $\mathrm{Ca}$ from Catalão I perovskite and produce anatase instead rutile. Nesbitt et al. (1981) suggest that in a variety of groundwater and hydrothermal systems, $\mathrm{P}\left(\mathrm{CO}_{2}\right)$ is sufficient to shift the equilibrium towards $\mathrm{TiO}_{2}$ plus calcite, according to the following reaction:

$\mathrm{CaTiO}_{3}+\mathrm{CO}_{2}=\mathrm{TiO}_{2}$ (rutile) $+\mathrm{CaCO}_{3}$

At Catalão-I this reaction was a little different due to the high $\mathrm{Mg}$ activity (product of the olivine alteration) which results in the crystallization of dolomite instead of calcite and anatase instead rutile.

The deuteric alteration of perovskite involving progressive leaching of $\mathrm{Ca}$ from perovskite was described by Mitchel \& Chakhmouradian (1998). They also show that the perovskite from the Sebljavr carbonatitic complex (Kola Peninsula, Russia) is replaced initially by anatase plus calcite and then by ilmenite and ancylite-(Ce). According to them, the crystallization of ilmenite after anatase (increase in $\mathrm{Fe}^{2+}$ activity at the final stages) can be described by the following reaction scheme:

$$
\begin{gathered}
2 \mathrm{TiO}_{2}+2 \mathrm{Fe}^{2+}+2 \mathrm{H}_{2} \mathrm{O}= \\
\text { anatase } \\
\text { ilmenite }
\end{gathered}
$$

They noticed that the precipitation of calcite and the replacement of anatase by ilmenite would decrease the stability of the carbonate complexes, and initiated crystallization of the LREE minerals ancylite-(Ce) and lucasite-(Ce). Under microscopic observations we verify that the ilmenite from Catalão-I is formed during a magmatic stage of crystallization, and the anatase belongs to a

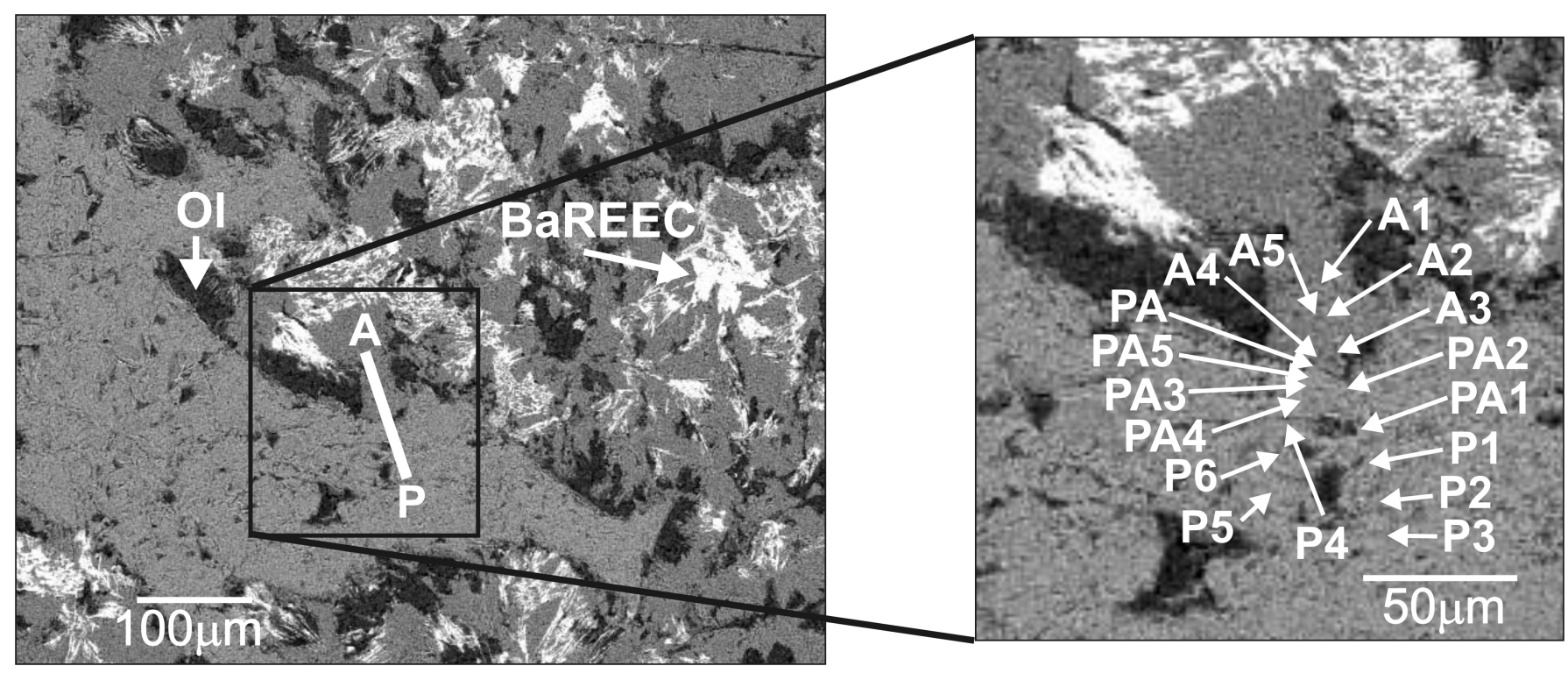

Figure 1: Back-scattered photomicrograph showing locality of analyses. $P$ - $A=$ perovskite-anatase profile; Ol = altered olivine; $B a R E E C=$ Barium and rare-earth elements carbonate; $\rightarrow$ Raman analyses. 
secondary paragenesis. Then, in Catalão I, the ilmenite and anatase genesis does not follow the reaction described above. In this alkaline massif, with the alteration process, REE and other elements concentrated in the perovskite are leached and precipitated as BaLREEC carbonate (see Fig. 1). The absence of titanite reflects the overall low activity of silica in the carbonatite system.

The analyses of perovskite are presented in Table 1 and of anatase in Table 2. The perovskite and anatase totals are around 97\% probably due the presence of REE not analyzed, the microporosity, and the presence of crystalline defects.

$\mathrm{Ca}, \mathrm{Ti}, \mathrm{Si}, \mathrm{Mg}, \mathrm{Nb}, \mathrm{Zr}, \mathrm{Na}, \mathrm{Fe}$ and Ce distribution maps were made on the same region where compositional profiles, EDS, EMPA and Raman analyses were done (see Fig. 1). The analyzed area is choused after optical microscopic observations where perovskite is partially replaced by anatase. The element distribution maps indicated that $\mathrm{Ca}, \mathrm{Ti}, \mathrm{Si}$ and $\mathrm{Mg}$ have different concentrations in the sample. Elevated $\mathrm{Si}$ and $\mathrm{Mg}$ define the areas of altered olivine; while Ca marks the perovskite and $\mathrm{Ti}$, the anatase (Fig. 2). The map of $\mathrm{Ca}$ distribution shows high $\mathrm{Ca}$ contents in the perovskite and much lower in anatase. This element was leached during the pseudomorphic alteration. Chemical analyses do not show any variation in the level of $\mathrm{Ca}$ across the perovskite grain. It is interpreted here as a consequence of "total" leaching of Ca from perovskite grain with no intermediate $\mathrm{Ca}$ phases.

Mass balance calculations, using the equations proposed by Gresens, 1967, were made for the pair perovskite-anatase (using Ti as immobile element). It indicate that $\mathrm{Ca}, \mathrm{Nd}, \mathrm{Ce}$ and $\mathrm{Na}$ are leached and $\mathrm{Ti}, \mathrm{Si}, \mathrm{Mg}, \mathrm{Zr}, \mathrm{Nb}$ and $\mathrm{Fe}$ are relatively concentrated. According to Myhra et al. (1984), perovskite-type rapidly equilibrates with the fluid phase through precipitation of alkaline-earth carbonates and development of a surface layer enriched in $\mathrm{TiO}_{2}$. The map of $\mathrm{Ti}$

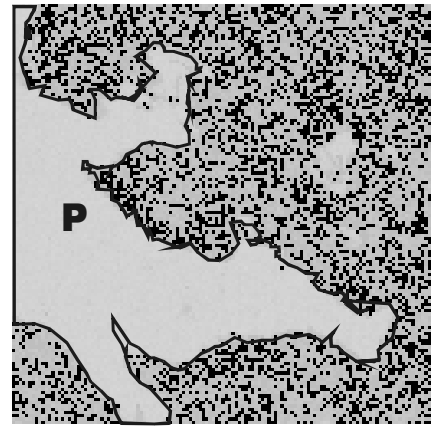

Ca

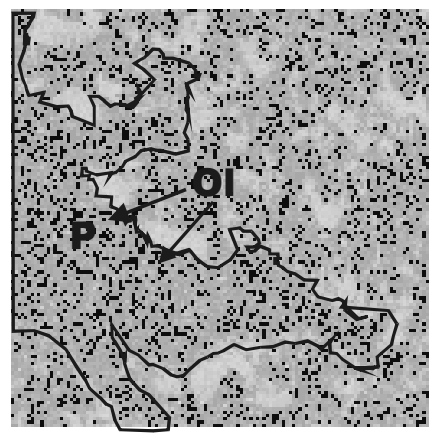

Si

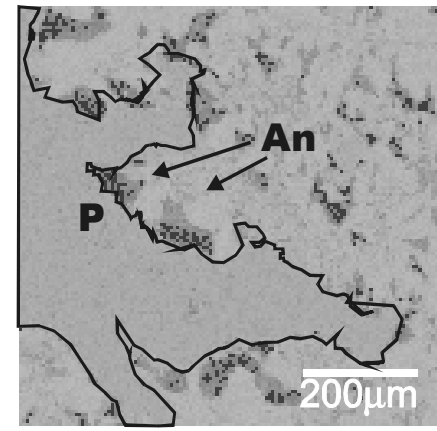

Ti

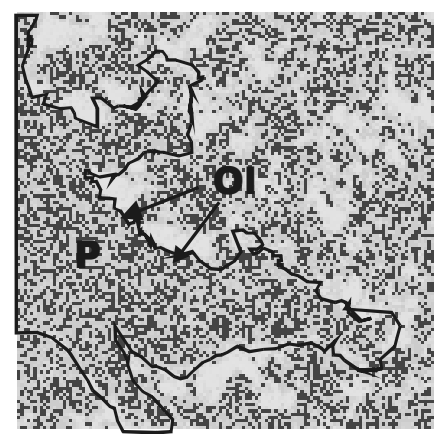

Mg
Figure 2 - Maps of Ca, Ti, Si and Mg distributions. distribution and the chemical analyses along the PA profile (Fig. 1) show that similar processes occurred at Catalão I. Ti behaves as "immobile" element during the alteration process.

RAMAN SPECTROSCOPY The perovskite and anatase were also examined using Raman spectroscopy. Raman spectra were acquired along the PA profile (Fig. 1). According to Gillet et al. (1993), Raman spectra of perovskite typically consist of two broad bands at 150-600 and 650-850 $\mathrm{cm}^{-1}$. On the lower frequency band $\left(150-600 \mathrm{~cm}^{-1}\right)$, sharp peaks are superimposed. The spectra of Catalão-I perovskite (Fig. 3) are similar to those described by Gillet et al. (1993), but three additional broad bands appear in the lower frequencies region $\left(509,635,794 \mathrm{~cm}^{-1}\right)$. The analysis P4 (Fig. 3a) presents a peak at $400 \mathrm{~cm}^{-1}$ that in other perovskite analyses $(\mathrm{P} 1$, P2, P3 and P5) appears as a band. The vibration at $470 \mathrm{~cm}^{-1}$
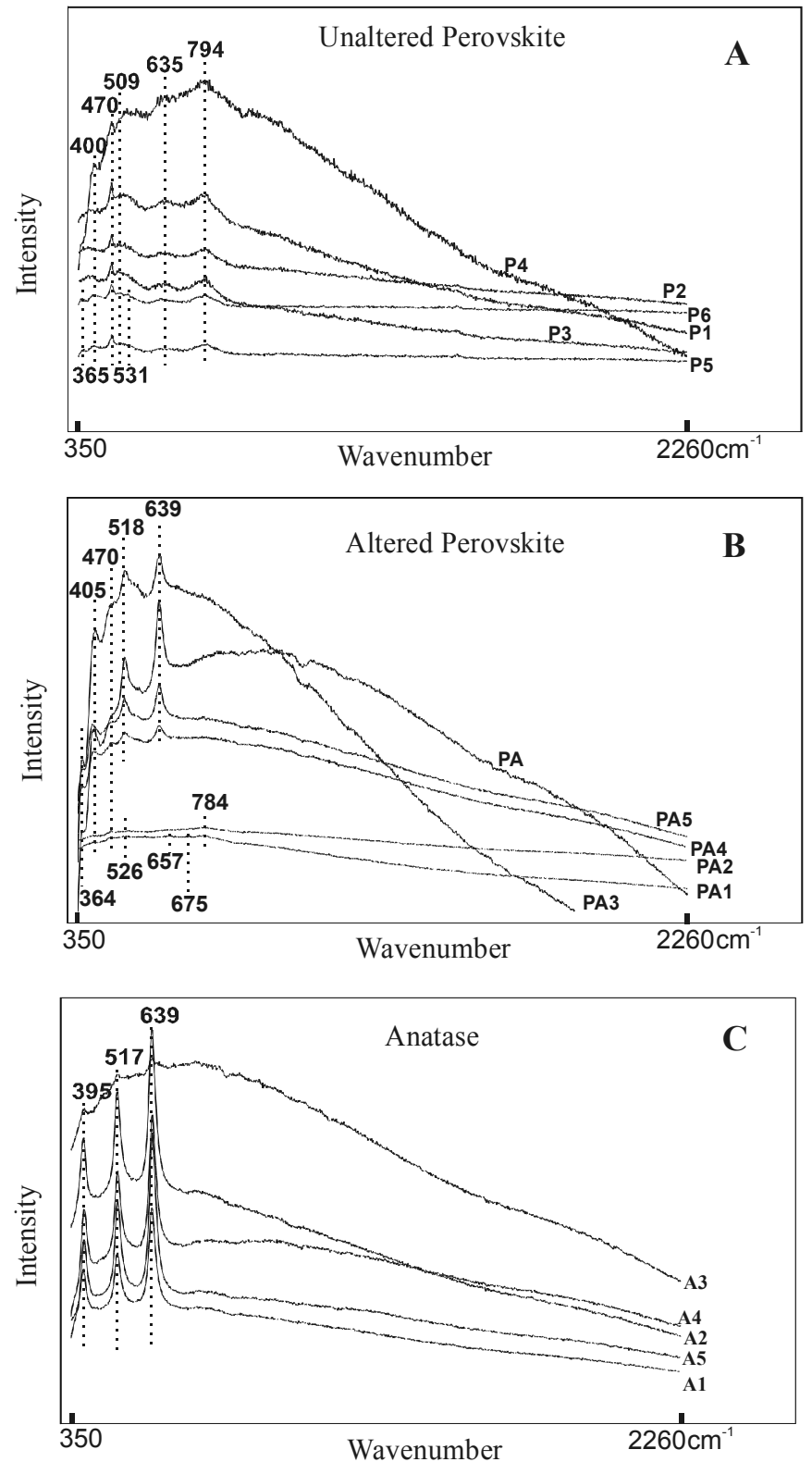

Figure 3 - Raman spectra of perovskite, altered perovskite and anatase. 
Table 1 - Chemical composition of perovskite from Catalão I Alkaline Complex.

\begin{tabular}{lcccccccccc}
\hline \multicolumn{1}{c}{ Sample } & P1 & P2 & P3 & P4 & P5 & P6 & P7 & P8 & P9 & P10 \\
\hline $\mathrm{CaO}$ & 34.90 & 35.05 & 34.68 & 34.85 & 35.13 & 35.11 & 34.89 & 34.84 & 34.90 & 34.81 \\
$\mathrm{Na}_{2} \mathrm{O}$ & 0.65 & 0.58 & 0.60 & 0.65 & 0.59 & 0.56 & 0.57 & 0.48 & 0.58 & 0.60 \\
$\mathrm{La}_{2} \mathrm{O}_{3}$ & 1.32 & 1.26 & 1.28 & 1.33 & 1.29 & 1.30 & 1.32 & 1.26 & 1.39 & 1.39 \\
$\mathrm{Ce}_{2} \mathrm{O}_{3}$ & 3.20 & 3.15 & 3.09 & 3.73 & 3.14 & 3.17 & 3.31 & 3.05 & 3.07 & 3.08 \\
$\mathrm{Nd}_{2} \mathrm{O}_{3}$ & 0.90 & 1.17 & 1.15 & 1.07 & 0.99 & 1.01 & 1.06 & 1.05 & 1.05 & 1.06 \\
$\mathrm{MgO}$ & 0.02 & 0.02 & n.d. & 0.01 & n.d. & n.d. & 0.02 & 0.01 & 0.01 & n.d. \\
$\mathrm{Fe}_{2} \mathrm{O}_{3}$ & 1.82 & 1.79 & 1.77 & 1.67 & 1.73 & 1.68 & 1.70 & 1.69 & 1.81 & 1.74 \\
$\mathrm{TiO}_{2}$ & 53.91 & 53.15 & 54.10 & 53.41 & 53.34 & 53.31 & 53.37 & 52.99 & 52.73 & 53.42 \\
$\mathrm{Nb}_{2} \mathrm{O}_{3}$ & 0.93 & 0.93 & 0.78 & 0.76 & 0.77 & 0.82 & 0.87 & 0.92 & 0.81 & 0.89 \\
$\mathrm{ZrO}{ }_{2}$ & 0.12 & 0.17 & 0.13 & 0.17 & 0.19 & 0.19 & 0.25 & 0.22 & 0.31 & 0.17 \\
$\mathrm{SiO}_{2}$ & 0.03 & 0.01 & n.d. & n.d. & n.d. & n.d. & n.d. & n.d. & 0.01 & n.d. \\
$\mathrm{Total}^{2}$ & 97.80 & 97.28 & 97.58 & 97.65 & 97.17 & 97.15 & 97.36 & 96.51 & 96.67 & 97.16 \\
\hline $\mathrm{Ca}$ & 0.90 & 0.91 & 0.89 & 0.90 & 0.91 & 0.91 & 0.90 & 0.91 & 0.91 & 0.90 \\
$\mathrm{Na}$ & 0.03 & 0.03 & 0.03 & 0.03 & 0.03 & 0.03 & 0.03 & 0.02 & 0.03 & 0.03 \\
$\mathrm{La}$ & 0.01 & 0.01 & 0.01 & 0.01 & 0.01 & 0.01 & 0.01 & 0.01 & 0.01 & 0.01 \\
$\mathrm{Ce}$ & 0.03 & 0.03 & 0.03 & 0.03 & 0.03 & 0.03 & 0.03 & 0.03 & 0.03 & 0.03 \\
$\mathrm{Nd}$ & 0.01 & 0.01 & 0.01 & 0.01 & 0.01 & 0.01 & 0.01 & 0.01 & 0.01 & 0.01 \\
$\mathrm{Fe}$ & 0.03 & 0.03 & 0.03 & 0.03 & 0.03 & 0.03 & 0.03 & 0.03 & 0.03 & 0.03 \\
$\mathrm{Ti}$ & 0.97 & 0.97 & 0.98 & 0.97 & 0.97 & 0.97 & 0.97 & 0.97 & 0.96 & 0.97 \\
$\mathrm{Nb}$ & 0.01 & 0.01 & 0.01 & 0.01 & 0.01 & 0.01 & 0.01 & 0.01 & 0.01 & 0.01 \\
$\mathrm{Total}$ & 1.99 & 2.00 & 1.99 & 2.00 & 1.99 & 2.00 & 1.99 & 1.99 & 1.99 & 1.99 \\
\hline
\end{tabular}

* Strontium in all perovskite analyses was below detection limits.

** Iron as $\mathrm{Fe} 3+$, according to Muir et al. (1984).

n.d. $=$ not detected

Table 2 - Chemical composition of anatase from Catalão I Alkaline Complex.

\begin{tabular}{|c|c|c|c|c|c|c|c|c|c|c|}
\hline Sample & A1 & A2 & A3 & A4 & A5 & A6 & A7 & A8 & A9 & A10 \\
\hline $\mathrm{SrO}$ & n.d. & n.d. & 0.01 & 0.04 & n.d. & n.d. & n.d. & n.d. & n.d. & n.d. \\
\hline $\mathrm{CaO}$ & 0.12 & 0.18 & 0.17 & 0.19 & 0.13 & 0.14 & 0.46 & 0.39 & 0.16 & 0.24 \\
\hline $\mathrm{Na}_{2} \mathrm{O}$ & n.d. & 0.02 & n.d. & 0.01 & n.d. & n.d. & n.d. & 0.04 & n.d. & n.d. \\
\hline $\mathrm{La}_{2} \mathrm{O} 3$ & n.d. & n.d. & n.d. & n.d. & n.d. & n.d. & n.d. & n.d. & n.d. & n.d. \\
\hline $\mathrm{Ce}_{2} \mathrm{O}_{3}$ & 0.23 & 0.20 & 0.21 & 0.36 & 0.04 & 0.14 & 0.17 & 0.23 & 0.15 & 0.07 \\
\hline $\mathrm{Nd}_{2} \mathrm{O}_{3}$ & 0.04 & n.d. & n.d. & 0.09 & 0.07 & n.d. & 0.03 & n.d. & n.d. & n.d. \\
\hline $\mathrm{MgO}$ & 0.04 & 0.05 & 0.04 & 0.09 & 0.02 & 0.03 & 0.03 & 0.03 & 0.01 & 0.01 \\
\hline $\mathrm{Fe}_{2} \mathrm{O}_{3}$ & 2.21 & 2.11 & 1.40 & 1.87 & 1.93 & 1.78 & 2.68 & 2.85 & 2.69 & 2.07 \\
\hline $\mathrm{TiO}_{2}$ & 92.64 & 93.27 & 93.16 & 92.39 & 93.34 & 93.68 & 91.89 & 92.91 & 92.35 & 93.86 \\
\hline $\mathrm{Nb}_{2} \mathrm{O}_{3}$ & 1.42 & 1.32 & 1.74 & 1.59 & 1.47 & 1.27 & 1.80 & 1.49 & 1.44 & 1.47 \\
\hline $\mathrm{ZrO}_{2}$ & 0.34 & 0.24 & 0.28 & 0.22 & 0.25 & 0.30 & 0.38 & 0.29 & 0.33 & 0.23 \\
\hline $\mathrm{SiO}_{2}$ & 0.37 & 0.47 & 0.44 & 0.69 & 0.24 & 0.15 & 0.31 & 0.22 & 0.33 & 0.22 \\
\hline Total & 97.41 & 97.86 & 97.45 & 97.54 & 97.49 & 97.49 & 97.75 & 98.45 & 97.46 & 98.17 \\
\hline \multicolumn{11}{|c|}{ Structural formulae based on 2 atoms of oxygen } \\
\hline $\mathrm{Ca}$ & 0 & 0 & 0 & 0 & 0 & 0 & 0.01 & 0.01 & 0 & 0 \\
\hline $\mathrm{Fe}$ & 0.02 & 0.02 & 0.01 & 0.02 & 0.02 & 0.02 & 0.03 & 0.03 & 0.03 & 0.02 \\
\hline $\mathrm{Ti}$ & 0.97 & 0.97 & 0.97 & 0.96 & 0.97 & 0.97 & 0.96 & 0.96 & 0.96 & 0.97 \\
\hline $\mathrm{Nb}$ & 0.01 & 0.01 & 0.01 & 0.01 & 0.01 & 0.01 & 0.01 & 0.01 & 0.01 & 0.01 \\
\hline $\mathrm{Si}$ & 0.01 & 0.01 & 0.01 & 0.01 & 0 & 0 & 0 & 0 & 0 & 0 \\
\hline Total & 1.01 & 1.01 & 1.00 & 1.00 & 1.00 & 1.00 & 1.01 & 1.01 & 1.00 & 1.00 \\
\hline
\end{tabular}

** Iron as $\mathrm{Fe} 3+$, according to Muir et al. (1984).

n.d. $=$ not detected 
Vitor Paulo Pereira et al.

Table 3 - Raman modes of perovskite and anatase from Catalão I Alkaline Complex.

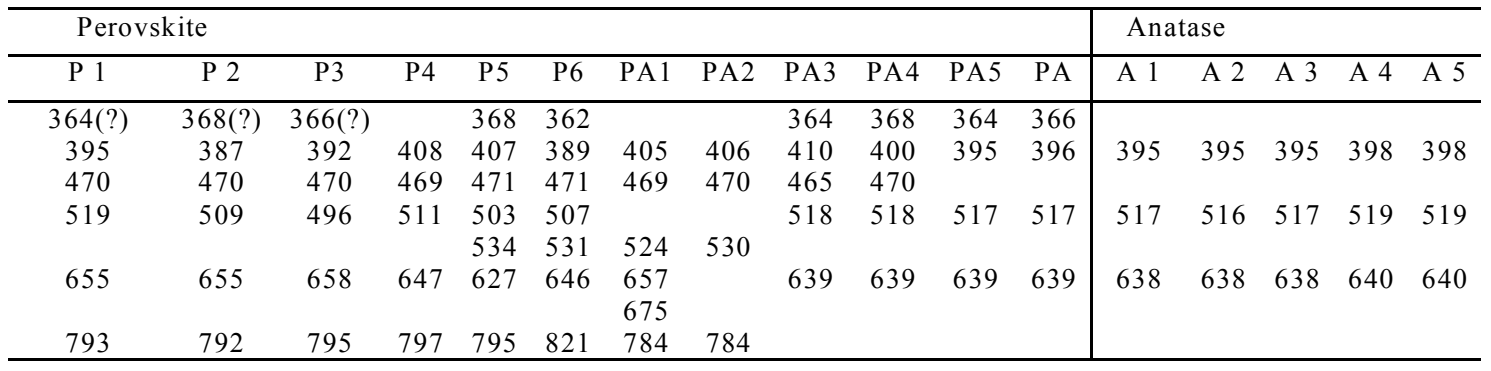

correspond to a sharp peak in all unaltered perovskite analyses.

Table 3 presents the Raman modes of perovskite and anatase from Catalão-I (sites of analyses in Fig. 1).

With alteration, some perovskite bands become broader, change their frequency, decrease its intensity, or disappear (Table 1 and Fig. 3). The 387-395 $\mathrm{cm}^{-1}$ perovskite band decreases in amplitude and shifts to $405-406 \mathrm{~cm}^{-1}$. The $395 \mathrm{~cm}^{-1}$ band reappear in anatase as a sharp peak. The $496-519 \mathrm{~cm}^{-1}$ band has a large vibration mode. In the altered perovskite, it is located at 517-519 $\mathrm{cm}^{-1}$, that is preserved in the anatase structure. The position of the $627-585 \mathrm{~cm}^{-1}$ band shifts with alteration to $639 \mathrm{~cm}^{-1}$, and does not change in the anatase spectra. The vibration modes that are destroyed by the alteration and do not appear in the anatase spectra are described below. The $364-368 \mathrm{~cm}^{-1}$ band has larger variations in amplitude and in some spectra it does not appear. A characteristic $465-470 \mathrm{~cm}^{-1}$ sharp peak persists in the perovskite spectra to the final stage of alteration, but disappears in the anatase spectra. The $524-534 \mathrm{~cm}^{-1}$ band is a vibration mode that occurs in some perovskite analyses. The $675 \mathrm{~cm}^{-1}$ band appears only in the spectrum of the altered perovskite. However, the $784-821 \mathrm{~cm}^{-1}$ band disappears at the "beginning" of the alteration. These variations in the frequency and amplitude of the Raman modes probably reflect the chemical heterogeneity of our samples (see Fig. 2). With the leaching of calcium the structure collapses to form anatase.

It is possible to verify that the amplitude of some spectral bands increases from the unaltered to the altered perovskite, as the 518 and 639 bands in the PA3 sample. This increase probably indicates changes in the orientation of $\mathrm{TiO}_{6}$ that modify the vibration modes. A similar process occurs in connection with the upon transition of the altered perovskite to anatase.

DISCUSSIONS AND CONCLUSIONS Field observations and laboratory analyses of Catalão I rocks made possible the identification of "phoscorites" and pyroxenites followed by the intrusion of carbonatites. The reaction with $\mathrm{CO}_{2}$ generated a secondary paragenesis composed of tetraferriphlogopite, anatase and Ba-LREE carbonate. The rare-earth elements are inherited from the perovskite and $\mathrm{Ba}$ is probably derived from the carbonatitic fluid. The leaching of calcium from the perovskite and magnesium from the olivine contributed to the crystallization of dolomite.

The Raman spectra between perovskite and anatase confirm that there is an alteration front. However, it does not show a "pure amorphous Ti-layer" ( $>1 \mathrm{~mm}$ ) at the transitional region. All analyses show the $\mathrm{TiO}_{6}$ vibration modes and the increase of background intensity that could be related with the presence of an amorphous phase or the presence of weakly bonded water molecules or structural groups, as described by Nasdala et al. (1995) to metamictized zircons.

The Raman spectra confirm the existence of an intermediate phase composed by altered perovskite preceding the crystallization of anatase. This phase is characterized by some perovskite peaks that did not change their frequency and amplitude during alteration. Some bands are destroyed before the structural change that forms anatase. Their relative intensity probably decreases with the increase of alteration. The vibration modes which persist through the alteration indicate that there is not a total dissolution of crystals. The alteration of perovskite by the carbothermal fluid culminates with the crystallization of anatase when the calcium is "completely" leached and the structure collapses. It does not follow the stepwise conversion proposed by Banfield \& Veblen (1992) that involves calcium leaching in two stages during weathering of perovskite to anatase. In both processes the structural mechanisms responsible for the perovskite (corner-sharing octahedra) alteration to anatase (edge-sharing octahedra) are continuing to be unclear. The fundamental building-blocks approach (Moore 1986, Veblen 1991) continues not being understood in this case. The limit between altered and unaltered perovskite is unclear because it is an heterogeneous alteration and different Raman vibration modes behave differently. The bands in altered perovskite shift, become broader and change intensity probably due to the increase of disorder of the octahedra orientations, and due to the presence of submicron domains of anatase and/or an amorphous phase. So, the Raman spectra of altered perovskite contain bands that correspond to the sharp peaks of anatase.

Raman spectroscopy does not permit to verify if the reaction involves direct structural inheritance, but it provides evidence that an intermediate phase occurs before the collapse of perovskite structure to form anatase.

Acknowledgments This work was financially supported by Programa de Núcleos de Excelência (PRONEX-FAURGS/CNPq662179978). We thank Dr. Naira Maria Balzaretti of the Laboratory of High Pressures of the Physics Institute (Federal University of Rio Grande do Sul - Brazil) for providing the Raman spectra and the $\mathrm{RBG}$ referees for the important suggestions.

\section{References}

Baecker M. L. 1983. A mineralização de nióbio no solo residual laterítico e a petrografia das rochas ultramáficas-alcalinas do domo de Catalão I, GO. Dissertação de Mestrado, Inst. Geoc., UnB, 113 p.

Banfield J. F. \& Veblen D. R. 1992. Conversion of perovskite to anatase and $\mathrm{TiO}_{2}$ (B): A TEM study and the use of fundamental building 
blocks for understanding relationships among the $\mathrm{TiO}_{2}$ minerals. Am. Mineral., 77:545-557

Banfield J.F., Jones B.F., Veblen D.R. 1991a. An AEM-TEM study of weathering and diagenesis, Albert Lake, Oregon, II. Diagenetic modifications of the sedimentary assemblage. Geochim. Cosmochim. Acta, 55:2781-2819

Banfield J.F., Veblen D.R., Smith D.J. 1991 b. The identification of a new $\mathrm{TiO}_{2}$ mineral as $\mathrm{TiO}_{2}$ (B) by structure determination using highresolution microscopy, image simulation, and distance-least-squares refinement. Am. Mineral., 76:343-353

Carvalho W. T. 1974 a. Aspectos geológicos e petrográficos do Complexo Ultramáfico - Alcalino de Catalão I, GO. In: SBG, Congr. Bras. Geol., 28, Porto Alegre, Anais, 5:107-123

Carvalho W. T. 1974b. Trabalho de pesquisa mineral desenvolvido no Complexo Ultramáfico - Alcalino de Catalão I, GO. In: SBG, Congr. Bras. Geol., 28, Porto Alegre, 5:251-272

Chakhmouradian A.R. \& Mitchell R.H. 2000. Occurrence, alteration patterns and compositional variation of perovskite in kimberlites. Can. Mineral., 38:975-994

Gillet P., Fiquet G., Daniel I. 1993. Raman spectroscopy at mantle pressure and temperature conditions experimental set-up and example of $\mathrm{CaTiO}_{3}$ perovskite. Geophys. Res. Lett., 20:1931-1934

Gresens R. L. 1967. Composition-volume relationship of metasomatism. Chem. Geol., 2:47-65

Hishita S., Mutoh I., Kuomoto K., Yanagida H. 1983. Inhibition mechanism of the anatase-rutile phase transformation by rare earth oxides. Ceram. Internat., 9:61-67

Kukharenko A.A., Orlova M.P., Bagdasarov E.A., Rimskaja-Korsakova O.M., Nefedov E.I., Iljinskii G.A., Abakumova N.B. 1965. Caledonian complex of ultrabasic and alkaline rocks, and carbonatites from Kola Peninsula and Northern Karelia. Nedra, 772pp. (in Russian).

Mitchell R.H. 1986. Kimberlites: mineralogy, geochemistry and petrology. New York, Plenum Press, 441pp.

Mitchell R. H. 1996. Perovskites: a revised classification scheme for an important rare earth element host in alkaline rocks. In: A.P. Jones, F. Wall, C.T. Williams (eds.) Rare Earth Minerals: Chemistry, Origin and Ore Deposits. London, Chapman \& Hall, pp.:41-76

Mitchell R.H. \& Chakhmouradian A.R. 1998. Instability of perovskite in a $\mathrm{CO}_{2}$-rich environment: examples from carbonatite and kimberlite. Can. Mineral., 36:939-952

Moore P.B. 1986. Quartz: variation on a theme. Am. Mineral., 71:540546

Muir J.J., Metson J. B., Bancroft G. M. 1984. ${ }^{57} \mathrm{Fe}$ Mössbauer spectra of perovskite and titanite. Can. Mineral., 22:689-694

Myhra S., Savage D., Atkinson A., Rivière J.C. 1984. Surface modification of some titanate minerals subjected to hydrothermal chemical attack. Am. Mineral., 69:902-909

Nasdala L., Irmer G., Wolf D. 1995. The degree of metamictization in zircon: a Raman spectroscopic study. Eur. J. Mineral., 7:471- 478

Nesbitt H.W., Bancroft G.M., Fyfe W.S., Karkhanis S.N., Nishijima A., Shin S. 1981. Thermodynamic stability and kinetics of perovskite dissolution. Nature, 289:358-362

Pereira V.P. 1995. A alteração do Maciço alcalino-Carbonatítico de Catalão-I - GO. Evolução mineralógica. Tese de Doutorado, Inst. Geociências, Universidade Federal do Rio Grande do Sul, 286 p.

Post J.E. \& Burnham C.W. 1986. Ionic modeling of mineral structures and energies in the electron gas approximation: $\mathrm{TiO}_{2}$ polymorphs, quartz, forsterite, diopside. Am. Mineral., 71:142-150

Ringwood A.E., Kesson S.E., Ware N.G., Hibberson W.O, Major A. 1979. The SYNROC process; a geochemical approach to nuclear waste immobilization. Chem. Journal, 13:141-165

Veblen D.R. 1991. Polysomatism and polysomatic series: A review and applications. Am. Mineral., 76:801-826

Manuscrito A 1470

Recebido em 7 de outubro de 2003

Revisão dos autores em 16 de fevereiro 2005 Revisão aceita em 6 de março de 2005 